\title{
Seroprevalence of Australia antigen (HbsAg) among blood donors in local population
}

\author{
Kokani M.J. ${ }^{1}$, Menapara C.B. ${ }^{2}$ \\ ${ }^{1}$ Dr. Mayur J. Kokani, Assistant Professor, ${ }^{2}$ Dr. Chiragkumar B. Menapara, Assistant Professor both authors are affiliated \\ with Department of Pathology, GMERS Medical College and Hospital, Junagadh, Gujarat, India
}

Corresponding Author: Dr.Chiragkumar B. Menapara, Assistant Professor, Department of Pathology, GMERS Medical College and Hospital, Junagadh, Gujarat, India. E-mail: mkokon11@gmail.com

\begin{abstract}
Introduction: Transfusion of Blood \& Blood Components is one of the four recognized modes of Hepatitis B virus infection and HBsAg or Australia Antigen in the serum is the earliest marker of active HBV infection (acute/chronic) being detectable even before elimination of transaminases and onset of clinical illness. Various strategies are being used to reduce this transfusion transmitted infection. Objectives: To determine the Seroprevalence of HBsAg among blood donors in and around Junagadh (Gujarat) and to compare it withthat of other regions in India. Methods: The study was conducted on apparently healthy blood donors over a period of 3 years from January-2015 to December-2017 at Blood Bank, Department of Pathology, GMERS Medical College and Hospital, Junagadh in order to assess the prevalence of hepatitis B virus infection. A total number of 18368 blood donors were included in this study. Both rapid HBsAg card test and HBsAg ELISA test were used for this study purpose. Result: Out of 18368 donors, 14102 (76.77\%) were inhouse donors and $4266(23.23 \%)$ were outdoor-camp donors. 17346 (94.44\%) were males \& $1022(5.56 \%)$ were females. Out of 18368 blood units, 487 (2.65\%) were discarded and out of them 109 (22.38\%) were HBsAg reactive. The Seroprevalence of HBsAg was found to be $0.59 \%$. Conclusion: Blood Donors are often found to be reactive for Australia Antigen and others. In order to reduce this Seroprevalence, more sensitive screening assays and appropriate donor selection are must.
\end{abstract}

Key words: Seroprevalence, Australia Antigen, Hepatitis B surface antigen

\section{Introduction}

Hepatitis B infection has become an issue of global importance. Hepatitis B causes an estimated 1-2 million deaths per year worldwide $[1,2]$ and it is estimated that there are 300 million carriers of Hepatitis B virus in the world. Countries are classified on the basis of endemicity of Hepatitis B virus infection into high (8\% or more, e.g. equatorial Africa, South East Asia, China, parts of South America), intermediate (2-7\%, e.g. Eastern Europe, Middle East, South Asia) or low $(<2 \%$, e.g. developed countries as North America and Australia) incidence countries [1]. The prevalence of chronic hepatitis B infection in India ranges from 2$10 \%$ as shown by different studies [2]. Transfusion associated hepatitis $\mathrm{B}$ viral infection (TAHBV) continues to be a major problem in India even after adoption of mandatory screening of hepatitis B surface antigen (HBsAg) by enzyme-linked immuno-sorbent assay (ELISA).

Manuscript received: $04^{\text {th }}$ November 2018

Reviewed: $14^{\text {th }}$ November 2018

Author Corrected: $22^{\text {th }}$ November 2018

Accepted for Publication: $28^{\text {th }}$ November 2018
The high incidence of TAHBV is reported in patients receiving multiple blood transfusions. This infection is the leading cause of morbidity and mortality not only because of the acute illness but also due to its chronic sequel like chronic hepatitis, cirrhosis and Hepatocellular carcinoma. Therefore we evaluated the seroprevalence of hepatitis B virus among blood donors. Hepatitis B is a major public health problem worldwide.

These endogenous microbial agents transmitted by bloodtransfusion have the following characteristics:

- Long incubation period

- Carrier or latent state

- Ability to cause asymptomatic/sub clinical infection

- Viability and stability in stored blood or plasma

- The hall mark is the persistence of infection.

Currently there are four recognized modes of hepatitis $\mathrm{B}$ infection - mother to child at birth (perinatal), contact with infected person(horizontal), sexual contact and 


\section{Original Research Article}

parenteral route through blood/fluids. HBsAg in the serum is the earliest marker of active HBV infection (acute/chronic) being detectable even before elimination of transaminases and onset of clinical illness.

The strategies used to reduce the transfusion transmitted infections includes improving donor selection, testing the donated blood for specific antibodies against infectious agents, using autologous transfusion $[3,4]$ but the transmission of disease still occurs [5] because of the inability to detect the disease in window phase of the infection, prevalence of asymptomatic carriers, false negative results, immunologically variant viruses and laboratory testing errors [6]. To understand and assess the magnitude and dynamics of transmission of a disease in a community and for its control and prevention and prevention control and prevention, the assessment and study of its prevalence is very important.

The samples were obtained for serological testing. HbsAg screening was done using rapid test kit based on the principle of a one-step immunoassay (Hepa-Card and Meril, India) and Erbalisa, Merilisa and Microscreen for qualitative detection (screening) of HBsAg in serum/plasma.Samples showing repeat test reactivity on both methods were considered positive and were included for calculation of seroprevalence.

\section{Materials \& Methods}

Place of the study: Blood Bank, Department of Pathology, GMERS Medical College \& Hospital, Junagadh, Gujarat (India)

Type of the study: Retrospective
Sampling Methods: Relevant data has been collected from previous blood bank records and includes a total number of 18368 blood donors both In-house \& Outdoor-camp. Duration of the study is 3 years from January 2015 to December 2017.

Donors were carefully selected for donation after satisfactorily answering the donors' questionnaire and passing the physical examination conducted by the physician-in charge.

All the collected blood units were screened for Hepatitis B surface antigen or Australia Antigen using two different testing methods namely (1) Rapid HBsAg card test (Hepa-Card and Meril) and (2) HBsAg ELISA test (Erbalisa, Merilisa and Microscreen) for qualitative detection (screening) of HBsAg in serum/plasma.

All the tests were performed according to the manufacturer's instructions with adequate controls.

Inclusion Criteria: Clinically and Apparently healthy individuals between 18 and 65 years of age and having body weight more than $45 \mathrm{~kg} \&$ Hemoglobin level more than $12.5 \mathrm{~g} / \mathrm{dl}$ with no significant history of any medical or surgical illness were qualified for the Donation Process.

Exclusion Criteria: Persons belonging to high risk groups such as patients with chronic diseases, professional blood donors, drug abusers, dialysis patients, pregnant ladies, patients treated in Thalassemia clinics, patients treated in Sexually Transmitted Disease clinics and sex workers were excluded from the process of blood donation and also from this present study.

\section{Results}

A total number of 18368 blood donors were screened over a period of 3 years from January 2015 to December 2017 . Out of them, $14102(76.77 \%)$ were in-house donors and 4266 (23.23\%) were outdoor-camp donors. Out of 18368 donors $17346(94.44 \%)$ were male donors and 1022(05.56\%) were female donors. Table no. 1 shows year wise percentage of Outdoor-camp donors and In-house donors. Table no. 2 shows year wise percentage of Male donors and Female donors.

Table No.-1: Trends in Outdoor-camp and In-house blood donation (Year-wise)

\begin{tabular}{|c|c|c|c|c|c|}
\hline Year & $\begin{array}{c}\text { Total No. of } \\
\text { Donors }\end{array}$ & $\begin{array}{c}\text { No. of In- } \\
\text { House Donors }\end{array}$ & $\begin{array}{c}\text { Percentage of In- } \\
\text { House Donors }\end{array}$ & $\begin{array}{c}\text { No. of Outdoor- } \\
\text { camp Donors }\end{array}$ & $\begin{array}{c}\text { Percentage of } \\
\text { Outdoor-camp Donors }\end{array}$ \\
\hline 2015 & 6609 & 5108 & 77.29 & 1501 & 22.71 \\
\hline 2016 & 5494 & 4140 & 75.35 & 1354 & 24.65 \\
\hline 2017 & 6265 & 4854 & 77.48 & 1411 & 22.52 \\
\hline Total & $\mathbf{1 8 3 6 8}$ & $\mathbf{1 4 1 0 2}$ & $\mathbf{7 6 . 7 7}$ & $\mathbf{4 2 6 6}$ & $\mathbf{2 3 . 2 3}$ \\
\hline
\end{tabular}


Original Research Article

Table No.-2: Trends in Male \& Female blood donation (Year-wise)

\begin{tabular}{|c|c|c|c|c|c|}
\hline Year & $\begin{array}{c}\text { Total No. of } \\
\text { Donors }\end{array}$ & $\begin{array}{c}\text { No. of Male } \\
\text { Donors }\end{array}$ & $\begin{array}{c}\text { Percentage of } \\
\text { MaleDonors }\end{array}$ & $\begin{array}{c}\text { No. of Female } \\
\text { Donors }\end{array}$ & $\begin{array}{c}\text { Percentage of } \\
\text { Female Donors }\end{array}$ \\
\hline 2015 & 6609 & 6229 & 94.25 & 380 & 5.75 \\
\hline 2016 & 5494 & 5206 & 94.76 & 288 & 5.24 \\
\hline 2017 & 6265 & 5911 & 94.35 & 354 & 5.65 \\
\hline Total & $\mathbf{1 8 3 6 8}$ & $\mathbf{1 7 3 4 6}$ & $\mathbf{9 4 . 4 5}$ & $\mathbf{1 0 2 2}$ & $\mathbf{5 . 5 5}$ \\
\hline
\end{tabular}

Out of 18368 blood units collected, 487 (2.65\%) units were discarded and out of them, 109 (22.38\%) units were HBsAg Reactive. The prevalence of Seropositivity for HBsAg was found to be $0.59 \%$.

Table-3: Incidence of HBsAg among donors during 2015-2017

\begin{tabular}{|c|c|c|c|c|c|}
\hline Year & $\begin{array}{c}\text { Total No. of } \\
\text { Donors }\end{array}$ & $\begin{array}{c}\text { Total No. of Bags } \\
\text { Discarded }\end{array}$ & $\begin{array}{c}\text { Percentage of } \\
\text { Bags Discarded }\end{array}$ & $\begin{array}{c}\text { Total No. of } \\
\text { HBsAg Reactive } \\
\text { Units }\end{array}$ & $\begin{array}{c}\text { Percentage of } \\
\text { HBsAg Reactive } \\
\text { Units }\end{array}$ \\
\hline 2015 & 6609 & 189 & 2.86 & 40 & 0.61 \\
\hline 2016 & 5494 & 202 & 3.68 & 42 & 0.76 \\
\hline 2017 & 6265 & 96 & 1.53 & 27 & 0.43 \\
\hline Total & $\mathbf{1 8 3 6 8}$ & $\mathbf{4 8 7}$ & $\mathbf{2 . 6 5}$ & $\mathbf{1 0 9}$ & $\mathbf{0 . 5 9}$ \\
\hline
\end{tabular}

Table-4: Percentage of Blood units discarded due to HBsAg Reactivity during 2015-2017

\begin{tabular}{|c|c|c|c|}
\hline Year & $\begin{array}{c}\text { Total No. of Bags } \\
\text { Discarded }\end{array}$ & $\begin{array}{c}\text { Total No. of HBsAg } \\
\text { Reactive Units }\end{array}$ & $\begin{array}{c}\text { Percentage of Blood units discarded } \\
\text { due to HBsAg Reactivity }\end{array}$ \\
\hline 2015 & 189 & 40 & 21.16 \\
\hline 2016 & 202 & 42 & 20.79 \\
\hline 2017 & 96 & 27 & 28.13 \\
\hline Total & $\mathbf{4 8 7}$ & $\mathbf{1 0 9}$ & $\mathbf{2 2 . 3 8}$ \\
\hline
\end{tabular}

Table no. 3 shows year wise percentages of Discarded Blood Units and HBsAg reactive Units. Table no. 4 shows Percentage of Blood units discarded due to HBsAg Reactivity during 2015-2017.

\section{Discussion}

Hepatitis B is one of the most common transfusion transmissible infections. The prevalence of this infection varies across the different geographical regions. Noting the trend of seroprevalence of hepatitis B is useful to assist the preventive strategies. The aim of this study was to determine the trend of seroprevalence of hepatitis B in Bijapur District, Karnataka over a period of two years six monthsHepatitis B is one of the most common transfusion transmissible infections. The prevalence of this infection varies across the different geographical regions. Noting the trend of seroprevalence of hepatitis B is useful to assist the preventive strategies. The aim of this study was to determine the trend of seroprevalence of hepatitis B in Bijapur District, Karnataka over a period of two years six monthsHepatitis B is one of the most common transfusion transmissible infections. The prevalence of this infection varies across the different geographical regions. Noting the trend of seroprevalence of hepatitis B is useful to assist the preventive strategies. The aim of this study was to determine the trend of seroprevalence of hepatitis B in Bijapur District, Karnataka over a period of two years six monthsHepatitis B is one of the most common transfusion transmissible infections. The prevalence of this infection varies across the different geographical regions. Noting the trend of seroprevalence of hepatitis B is useful to assist the preventive strategies. The aim of this study was to determine the trend of seroprevalence of Hepatitis B in Junagadh District, Gujarat over a period of three years.

Provision of safe blood is of paramount importance and its responsibility is solely with the blood transfusion service. Hepatitis B is a major health problem world wise and is associated with life-threatening complications. According to India's Drugs and cosmetics Act (1943), each blood unit has to be tested for hepatitis B infection [7]. According to India's Drugs and Cosmetics Act (1945), each blood unit has to be tested for hepatitis B virus infection (Drugs and Cosmetics Act 1940). About 5\% (300 millions), of world population has chronic infection HBV, which is major factor for developing of chronic liver cirrhosis and hepatocellular carcinoma. 


\section{Original Research Article}

Table-5: Comparison of Seroprevalence of HBsAg among Blood Donors in different other studies

\begin{tabular}{|l|c|c|c|}
\hline Name of Study & Year & Place & Seroprevalence \\
\hline Srikrishna et al [8] & 1999 & Bangalore & $1.86 \%$ \\
\hline Chhattoraj et al [9] & 2008 & Pune & $0.99 \%$ \\
\hline Karandeepsinh et al [10] & 2009 & Costal Karnataka & $0.62 \%$ \\
\hline Gagandeep Kaur et al [11] & 2010 & Chandigarh & $0.65 \%$ \\
\hline S Gulia et al [12] & 2011 & Vizianagaram & $2.48 \%$ \\
\hline Poojaba Jadeja et al [13] & 2011 & Udaipur, Rajasthan & $1.32 \%$ \\
\hline Present study & 2018 & Junagadh, Gujarat & $\mathbf{0 . 5 9 \%}$ \\
\hline
\end{tabular}

Among the 18368 screened samples, 109 of them (0.59\%) were found positive for HBsAg. Similar type of results was found in an Indian study during the year 2008 [17] and year 2015 [18]. In contrast, seropositivity in another study was observed to be as low as $1.55 \%$ in 1996 and $0.99 \%$ in2002 [19]. A community cluster survey on STD prevalence conducted in Tamil Nadu showed an HBsAg prevalence rate of about 5.7\% [20].

In our study, the overall Seroprevalence of HBsAg was observed to be $0.59 \%$. According to the WHO classification, this part of the Gujarat qualifies as a low prevalence area (less than $2 \%$ ). The data providing a picture of hepatitis B infection burden in India has come from HBsAg Seroprevalence studies (Table 5). Comparison with the other parts of India, the present study shows low Seroprevalence of hepatitis B infection in Gujarat.

If we compare the HBsAg positive in other developing countries of the world the rate is quite high as compared to India. Table 6 shows prevalence of HBsAg in other countries [14,15,16].

Table-6: Prevalence of HBsAg in other countries

\begin{tabular}{|c|c|}
\hline Name of the Country & Percentage of HBsAg Seropositivity \\
\hline Egypt & 39.4 \\
\hline Indonesia & 8.8 \\
\hline Ghana & 15.0 \\
\hline Nepal & 2.5 \\
\hline
\end{tabular}

Table 7 shows the burden of hepatitis B in rest of India as found by the sero-prevalence studies. In comparison with the other parts of India, our study shows seroprevalence of hepatitis B infection in Gujaratregion.

Table-7: Prevalence of HBsAg positive donors indifferent states of India [21, 22, 23, 24, 25].

\begin{tabular}{|c|c|}
\hline Place & Prevalence \\
\hline New Delhi & $2.23 \%, 2.76 \%$ \\
\hline Kerala & $3.1 \%$ \\
\hline Mudarai & $4 \%$ \\
\hline Tamilnadu & $1.37 \%$ \\
- Voluntary & $2.96 \%$ \\
\hline - Replacement & $0.99 \%$ \\
\hline Dehradun & $1.66 \%$ \\
\hline Kolkata & $2.25 \%$ \\
\hline Kanpur & $1.86 \%$ \\
\hline Bangalore & $0.35 \%$ \\
\hline Kasmir & \\
\hline
\end{tabular}

This variation in the prevalence of hepatitis B infection in different countries depends upon a mix of behavioral, environmental and host factors, incidence and age of primary infection. It is lowest in areas with high standards of living and highest in areas with low socioeconomic levels.

On comparison of the trends of hepatitis B positive among blood donors in 2015, 2016, and 2017. Positive cases of $0.61 \%$ 2015, in $20160.76 \%$ and in $20170.43 \%$ was noted. Rural population with lower literacy rate and a lack of 


\section{Original Research Article}

awareness about the disease and its mode of prevention may be the reason for increased incidence. However, screening of blood bank donors for HBsAg does not totally eliminate the risk of HBV infection through blood transfusion. Since, the absence of this marker in the serum does not exclude the presence of HBV infection, who lacked detectable HBsAg but whose exposure to HBV infection was indicated by a positive anti-HBc and HBV DNA, are a potential sources of HBV infection [26].

\section{Conclusion}

Blood donors represent apparently healthy population of a particular geographical region. Occasionally out of them, some people are found to be reactive for Australia Antigen and many other similar antigens as well as antibodies. So to reduce Seroprevalence of HBsAg, more sensitive screening assays and proper donor selection are must. Ensuring the safety of patients by reducing the residual risk of transfusion transmitted hepatitis is the concern of every transfusion center. Reduction in seroprevalence among voluntary donors requires an effective donor education and high quality selection programme especially during big blood donation camps. Along with advanced technology for donor screening and other factors such as public awareness, educational and motivational programs, and mass immunization programs help in decreasing the infection. Pre-donation counseling, donor self-exclusion and ensuring $100 \%$ voluntary blood donation will be effective in decreasing the hepatitis B infection rate. This study provides a helpful guide in reducing the residual risk of transfusiontransmitted hepatitis not only in India, but also in the other developing countries of the world. To conclude, with the implementation of strict selection criteria of donor as per the guidelines laiddown for blood banks in the gazette notification by the Government of India and use of sensitive laboratoryscreening tests, it is possible to decrease the incidence of seropositivity of transfusion-transmitted infectionsandimprove the blood product safety.

\section{Contribution from the Author}

- Dr. Mayur J. Kokani: Data collection, analysis and preparation of manuscript.

- Dr. Chiragkumar B. Menapara: Analysis and preparation of manuscript \& critical revision.

Findings: Nil; Conflict of Interest: Non initiated. Permission from IRB: Yes

\section{References}

1. Prevention of hepatitis B in India, An overview. World Health Organization, New Delhi; 2002.

2. Karandeep Singh, Sudha Bhat, ShameeShastry. Trend in Seroprevalence of Hepatitis B virus infection among blood donors of coastal Karnataka, India. J Infect Dev Ctries 2009;3(5) : 376-379.
3. WHO global health situation projection and estimates. 1992; WHO Geneva 1992.

4. Glynn SA, Kleinman SH, Wright DJ, et al. International application of the incidence rate/window period model. Transfusion. 2002 Aug;42(8):966-72.

5. Doddy RY, Notari EP, Stamer SL. Current prevalence and incidence of infectious disease markers and estimated window period risk in the American Red Cross Blood Donor Population. Transfusion; 2002; 42:238-40.

6. Klein HG. Will blood transfusion ever be safe enough? JAMA. 2000 Jul 12;284(2):238-40.

7. Bhattacharya $\mathrm{P}$, Chandra PK, Datta $\mathrm{S}$, et al. Significant increase in HBV, HCV, HIV and syphilis infections among blood donors in West Bengal, Eastern India 2004-2005: exploratory screening reveals high frequency of occult HBV infection. World J Gastroenterol. 2007 Jul 21;13(27):3730-3.

8. Srikrishna A, Sitalakshmi S, Damodar P. How safe are our safe donors? Indian J Pathol Microbiol. 1999 Oct; 42(4):411-6.

9. Chattoraj A, Behl R, Kataria VK. Infectious Disease Markers in Blood Donors. Med J Armed Forces India. 2008 Jan;64(1):33-5. doi: 10.1016/S0377-1237 (08) 80142-6. Epub 2011 Jul 21.

10. Karandeep Singh, Sudha Bhat, ShameeShastry. Trend in seroprevalence of Hepatitis B virus infection among blood donors of coastal Karnataka, India. J Infect Dev Ctries; 2009; 3(5): 376-379.

11. Gagandeep Kaur, SabitaBasu, Ravneet Kaur, Paramjeet Kaur, Shailja Garg. Patterns of infections among blood donors in a tertiary care centre: A retrospective study . The National Medical Journal of India;2010;23(3):147 -49.

12. Gulia S, Panda S, Sitaramam E, Reddy K. Seroprevalence Of Hepatitis B Virus Infection Among Blood Donors In Local Population. The Internet Journal of Pathology. 2010; Volume 12 Number.

13. Jadeja P, Kaur A, Shekha H. Trend in Seroprevalance of Hepatitis B Virus infection among 


\section{Original Research Article}

blood donors at a Tertiary Care Centre of Rajasthan, India. National journal of Medical Research, 2014volume 4,issue 3:page no-205 to 207

14. Allain JP, Candotti D, Soldan K, et al. The risk of hepatitis B virus infection by transfusion in Kumasi, Ghana. Blood. 2003 Mar 15;101(6):2419-25. Epub 2002 Oct 17.

15. Lt Col PK Gupta, Col H Kumar, Mr. Basannar, Brig M Jaiprakash . Transfusion Transmitted Infections in Armed Forces : Prevalence and Trends : MJAFI; $2006 ; 62: 348-350$

16. Arthur RR, Hassan NF, Abdallah MY, et al. Hepatitis C antibody prevalence in blood donors in different governorates in Egypt. Trans R Soc Trop Med Hyg. 1997 May-Jun;91(3):271-4.

17. Nilima S., Sawke, G.K., Chawla, S. Seroprevalence of common transfusion transmitted infections among blood donors. People's J. Sci. Res.2010; 3(1): 5-7.

18. Suresh B Sonth, Shilpa Gokale, Deepa Hadapad and Shivakumar S. Solabannavar. Prevalence of Hepatitis B Virus Infection among Blood Donors. IJCMAS,2015; 4(10):915-918.

19. Sharma RR, Cheema R, Vajpayee $M$, et al. Prevalence of markers of transfusion transmissible diseases in voluntary and replacement blood donors. Natl Med J India. 2004 Jan-Feb;17(1):19-21.

20. Kurien T, Thyagarajan SP, Jeyaseelan L, et al. Community prevalence of hepatitis $\mathrm{B}$ infection and modes of transmission in Tamil Nadu, India.Indian J Med Res. 2005 May;121(5):670-5.
21. Asim M, Ali R, Khan LA, et al. Significance of anti-HBc screening of blood donors and its association with occult hepatitis B virus infection: Implications for blood transfusion. Indian J Med Res. 2010 Sep; 132:312-7.

22. Chandrasekaran S, Palaniappan N, Krishnan V, et al. Relative prevalence of hepatitis $\mathrm{B}$ viral markers and hepatitis $\mathrm{C}$ virus antibodies (anti HCV) in Madurai, south India. Indian J Med Sci. 2000 Jul;54(7):270-3.

23. Rodenas JG, Bacasent LC, Que ER. The prevalence of $\mathrm{HBs} \mathrm{Ag}(+)$ and anti $\mathrm{HCV}(+)$ and anti $\mathrm{HCV}(+)$ among healthy blood donors at East Avenue Medical Center, Quezon City. Phil J of Gastroenterology. 2006;2;64-70.

24. Patil AV, Pawar SD, Pratinidhi AK. Study of prevalence, trend and correlation between infections disease markers of blood donors. Indian Journal of Hematology and Blood Transfusion.1996;14:95-102.

25. Mohd Younus Shah,MohdMubarikNaqash, Faizan Younus Shah. Seroprevalence of hepatitis b in healthy blood donors at a teaching hospital of Kashmir (skims medical college and hospital Bemina, Srinagar): a restrospective study of five years. Int J Res Med Sci. 2016 Feb;4(2):509-511.

26. Asim M, Ali R, Khan LA, et al. Significance of anti-HBc screening of blood donors and its association with occult hepatitis B virus infection: Implications for blood transfusion. Indian J Med Res. 2010 Sep;132:312-7.

\section{How to cite this article?}

Kokani M.J., Menapara C.B. Seroprevalence of Australia antigen (HbsAg) among blood donors in local population. Trop J Path Micro 2018;4(7):512-517.doi:10.17511/jopm.2018.i07.06. 